\author{
Eeva Rinne ${ }^{a}$
}

\title{
(Moni)kulttuurinen maailmankuva ja kuulumisen politiikka suomalaisissa peruskoulun oppikirjoissa ja nuorten kokemuksissa
}

\author{
Väitöstilaisuuden Lectio Praecursoria \\ Tampereen yliopisto 23.8.2019
}

\begin{abstract}
Nykypäivän Suomessa elää ja vaikuttaa hyvin moninainen joukko nuoria. He tulevat erilaisista lähtökohdista ja kulttu urisista taustoista, he harrastavat monenlaisia asioita ja identifioituvat erilaisiin etnisiin, kielellisiin, sukupuolisiin, seksuaalisiin ja vaikkapa osakulttuurisiin identiteetteihin. Heitä yhdistää erityisesti yksi asia: peruskoulu. Käytännössä kaikki Suomessa asuvat alaikäiset nuoret eli oppivelvolliset suorittavat peruskoulunsa hyväksytysti loppuun. Nuoret paitsi kohtaavat toisiaan koulujen käytävillä ja oppitunneilla saavat myös numeerisesti arvostellun todistuksen siitä, kuinka hyvin he osaavat koulun tarjoaman tietoperustan. Tällä todistuksella on myös vaikutusta heidän jatkokoulutusmahdollisuuksiinsa ja siten heidän muihin tulevaisuuden suunnitelmiinsakin.

Koululaitos ei ole suinkaan ainoa nuoria sosiaalistava instituutio. Myös esimerkiksi perinteinen ja sosiaalinen media, perheet ja erilaiset vertaisryhmät ovat tärkeitä tekijöitä nuorten maailmankuvien muodostumisprosesseissa. Usein onkin mahdotonta sanoa, mistä jokin tietty ajatus tai idea on lähtöisin. Koululaitosta voidaan kuitenkin pitää erityisen vahvana sosiaalistajana Suomessa, sillä koululaitoksen välittämä tietoperusta ja maailmankuva ovat institutionaalisesti säänneltyjä, eli ne perustuvat aina tiettyihin erikseen sovittuihin asioihin ja ilmiöihin. Vaikka esimerkiksi media on nykypäivänä hyvin läpitunkevassa asemassa nuorten maailmoissa, eivät kaikki heistä välttämättä seuraa samoja medioita. Koululaitos on kuitenkin perustaltaan kaikille sama.

Koulun tarjoama opetus tukeutuu moniin seikkoihin: opetussuunnitelmiin, opettajankoulutukseen, opettajakuntaan ja erilaisiin opetusvälineisiin ja -metodeihin. Koulukirjat ovat hyvin laajalti käytettyjä, ja ne noudattelevat virallista valtakunnallista opetussuunnitelmaa. Ne levittävät siis institutionaalisesti hyväksyttyä tietoperustaa ja käsitystä maailmasta. Tieto ei itsessään kuitenkaan ole välttämättä arvovapaata tai neutraalia, vaan se kietoutuu erilaisiin valtakysymyksiin, rajauksiin ja katsontakantoihin.
\end{abstract}


Näin ollen on merkityksellistä tarkastella sitä, millaista maailmankuvaa koulumaailma välittää nuorille ja millaisen maailmankuvan nuoret ovat sisäistäneet. Tämän väitöskirjan tavoitteena on hahmottaa koululaitoksen tuottamaa (moni)kulttuurista maailmankuvaa ja kuulumista luovaa politiikkaa sekä toisaalta nuorten kokemia ja sanallistamia käsityksiä maailmasta sekä omasta kuulumisen tunteestaan. Heidän omaksumansa maailmankuva ei kerro vain siitä, mitä tämän päivän nuoret ajattelevat ja mihin he uskovat, vaan heijastuu laajemminkin heidän toimintaansa.

Päädyin tutkimusaiheeni pariin ikään kuin vahingossa. Tein aikoinaan pro gradu -tutkielmani peruskoulun oppikirjojen tuottamasta tilallisesta maailmankuvasta ja tuolloin huomioni kiinnittyi kyseisten oppikirjojen toiseuttavaan puhuntaan. Samalla huomasin oppikirjojen tarjoaman maailmankuvan olevan tilallisesti varsin suppeasti rajautunut. Tajusin tämän heijastuneen itseasiassa myös omaan käsitykseeni maailmasta, sillä tietämyksessäni esimerkiksi Aasiasta tai Afrikasta oli suuria aukkoja. Aloin pohtimaan sitä, millaista tietoperustaa ja käsitystä maailmasta minulle oli koulussa opetettu, ja erityisesti sitä, millainen tuo tarjottu maailmankuva on nyt. Halusin tutkia aihetta lisää. Oppikirjatutkimus onkin lisääntynyt viime vuosina, ja se on ollut sävyltään aiempaa kriittisempää. Huomiota ovat kiinnittäneet muun muassa oppikirjojen normatiivinen sukupuoli-ideologia ja stereotyyppisyys, moniperspektiivisyyden puute, interkulttuuristen kohtaamisten pinnallisuus ja länsimaisten arvojen nähty paremmuus. Tästä huolimatta koen, että tutkimusta ei ole tehty likimainkaan tarpeeksi suhteessa siihen, kuinka tärkeä koulun ja sen opetuksen rooli on nuorten elämässä ja ylipäätään yhteiskunnassamme.

Väitöskirjani on aineistoltaan varsin laaja-alainen. Se tarkastelee Suomen suurimpien oppikirjakustantamojen peruskoulun maantiedon, historian ja yhteiskuntaopin 2000-luvulla painettuja oppikirjoja. Toisaalta väitöskirjassa tutkitaan myös 72:n pirkanmaalaisen nuoren käsityksiä maailmasta ja kuulumisestaan siellä. Tutkimus limittyy moniin yhteiskunnallisesti merkittäviin ilmiöihin: Millaista tietoperustaa koululaitos tuottaa? Mitä nuoret ajattelevat tilallisesta ja kulttuurisesta maailmasta? Liittyykö koululaitoksen levittämään maailmankuvaan toiseuttamista tai jopa rasistisia diskursseja ja miten tämä näkyy nuorten kokemuksissa?

Ensinnäkin maailma on yhä globaalimpi: ajatukset ja tiedot, ihmiset ja tavarat liikkuvat yhä enemmän ja nopeammin kansallisvaltioiden rajoista välittämättä. Mikäli kouluopetuksen tietoperusta keskittyy pääosin vain eurooppalaiseen ja läntiseen katsontakantaan, kuten väitöskirjani osoittaa, jää moni tärkeä asiaa avaamatta ja ymmärtämättä. Maailma on kokonaisuus, jonka eri osaset vaikuttavat toisiinsa. Lisäksi annettuun tietoperustaan voi liittyä erilaisia arvottavia elementtejä. On esimerkiksi merkityksellistä, kenelle annetaan toimijuus tai kuka jätetään vain toiminnan tai katseen kohteeksi oppikirjojen narratiiveissa. Myös esimerkiksi oppikirjoissa yleinen kansallisvaltiokeskeinen ajattelumalli on vain yksi tapa hahmottaa tilallista maailmaa, vaikka se on usein niin vahva, että sen taakse on vaikea nähdä.

Oppikirjat ovat yhteiskunnassamme käytännössä katsoen ainoita kirjoja, joita on ainakin näennäisesti pakko lukea. Vaikka nuorten käsitykset maailmasta ja sen ihmisistä sekä itsestään muuttuvat jossain määrin ajan kuluessa, tarjoaa koulu ja oppikirjat eräänlaiset pohjan tälle ajattelulle. Nuoret ovat jo itsessään vahvoja toimijoita ja tulevaisuudessa he ovat Suomen aikuisia vaikuttajia.

Väitöskirjani osoittaa, että voidaan puhua jopa oppikirjojen toiseuttavista diskursseista. Rasismi on perinteisesti tabu-aihe, ja sen tiedostamiseen tai kieltämiseen liittyy muun muassa syyllistämisen pelko, huumoriin tai leikkimielisyyteen vetoaminen ja toisaalta keskustelu sananvapaudesta (van Dijk 1987; Souto, Honkasalo \& Suurpää 2015). Vaikka oppikirjojen tuottamat diskurssit voidaan ymmärtää jossain määrin myös rasistisina, ei tämä johdu niinkään koululaitoksen tai oppikirjojen kirjoittajien rasistisuudesta, vaan nykyistä yhteiskuntajärjestystä luonnollistavista hegemonisista diskursseista, jotka ylläpitävät tietynlaista käsitystä maailmasta ja sen ihmisistä. Hegemoniset diskurssit ovat 
itsestään selvinä pidettyjä ja yleisiä ajattelumalleja tai väittämiä siitä, miten maailma toimii ja mikä on normaalia ja toivottavaa. Usein näitä ajattelumalleja ei edes tiedosteta tai huomata. Näin myös rasismista irtisanoutuvat saattavat uusintaa rasistisia ajattelumalleja ja toimintatapoja huomaamattaan (ks. myös Rastas 2005). Tämä ei kuitenkaan tarkoita sitä, että nämä diskurssit tulisi sivuuttaa tai hyväksyä, vaan sitä, että totunnaisia ajattelumalleja ja -tapoja tulisi tarkastella kriittisesti. Siksi rasismistakin pitäisi voida puhua. Rasismin ja erilaisuuden tuottamisen vastustaminen on moninainen ilmiö, joka voi keskittyä esimerkiksi valkoisuuden normin ja rotujärjestelmän purkamiseen, rasismin tunnistamiseen tai kulttuurien näkemiseen moninaisina (ks. esim. Rastas 2005; Souto 2010).

Kouluopetukseen on perinteisesti liittynyt myös kansallisen identiteetin opetuksen vaade. Ajatellaan, että vahvan jaetun kansallisen identiteetin kautta lapset ja nuoret sosiaalistetaan osaksi suomalaisuutta ja suomalaista yhteiskuntaa sekä aktiivisiksi toimijoiksi siellä. Mikäli tarjottu kansallinen identiteetti on sisällöltään suppea tai rajoittava, eivät kaikki siihen samastu, tai he kokevat tulevansa suljetuksi ulkopuolelle. Esimerkiksi mikäli suomalaisuutta rakennetaan kansallisuuden eikä kansalaisuuden varaan, voivat maahanmuuttajataustaiset lapset ja nuoret kokea itsensä erilaisiksi ja sulkea itsensä tämän suomalaisuuden ulkopuolelle. Tällöin kansallisen identiteetin yhdistävä voima saattaa kääntyä jopa hajauttavaksi.

Suomessa asuvilla nuorilla on erilaisia identiteettikokemuksia, ja heidän identiteettejään myös kategorisoidaan ulkopuolelta eli heidän ajatellaan olevan tietynlaisia esimerkiksi heidän ulkonäkönsä kuten ihonvärin perusteella. Aina ihmisen oma identiteettikokemus ja ulkoapäin määritelty identiteettikategoria eivät kohtaa. On raskasta, mikäli nuori kategorisoidaan aina jollain tapaa erilaiseksi tai ulkopuoliseksi. Tämä on ongelmallista, sillä ihmisillä on tarve tuntea itsensä hyväksytyksi.

Kouluopetus on käynyt viime vuosina läpi erilaisia murroksia. Yhteiskunnan läpikäymät vaiheet näkyvät aina myös kouluopetuksessa. Viime vuosina ovat puhuttaneet esimerkiksi oppikirjojen naiskuvan suppeus ja puute, johon onkin jossain määrin puututtu. Opetuksesta on haluttu tehdä tasa-arvoisempaa ja näkökulmaltaan laajempaa. Tässä prosessissa ollaan oman näkemykseni mukaan vielä puolitiessä.

Toinen runsaasti puhuttanut seikka on ollut uuteen opetussuunnitelmaan liitetty ilmiöoppiminen. Opetuksessa on haluttu huomioida laajempia asia- ja ilmiökokonaisuuksia ja opetuksen painopistettä on siirretty nuorille itselleen. Vaikka väitöskirjassani en perehdy varsinaisesti ilmiöoppimiseen, limittyy tutkimusaihe myös tähän ilmiöön. Nykyisellään oppikirjat edustavat aina jotakin oppialaa. Ne kertovat asioista rajatusti, jonkin katsontakannan kautta. Oppilaat puolestaan lukevat ja opettelevat asioita koetilanteita varten, jolloin heidän syvällinen ymmärryksensä asioista saattaa jäädä pinnalliseksi. Väitöskirjani valossa näyttää siltä, että tämä näkyy nuorten maailmankuvissa. Esimerkiksi moni aineistoni nuori ajattelee Afrikan olevan köyhä sen vuoksi, että siellä on kuivaa eikä maanosassa ole juurikaan kaupunkeja. Heille Afrikka edustaa käytännössä vain savimajojen täplittämää savannia ja köyhyydessä ja kurjuudessa eläviä ihmisiä, joita meidän länsimaalaisten täytyy auttaa. Historian oppitunneilla käsitelty imperialismi ja kolonialismi ovat jääneet monille nuorille siten vain historian kirjoihin liittyväksi ilmiöksi eivätkä he pohdi asiaa enää juurikaan maantiedon kirjoja läpikäydessään.

Maailmankuva ei ole ikinä valmis. Se muuttuu ja mukautuu ja vaihtelee tilanteiden mukaan. Voidaankin todeta, että täydellistä oppikirjaa ei ole olemassa. Väitöstutkimukseni perusteella oppikirjat kaipaavat kuitenkin moninaisempaa ja tasa-arvoisempaa otetta. Tutkimukseni pohjautuu kriittisen diskurssianalyysin perinteeseen. Sen tavoitteena on tuottaa muutosta ja edesauttaa parempaa maailmaa. Siksi tämä väitöskirjakin on osaltaan suomenkielinen monografia. On erityisen tärkeää tuottaa tietoa käytännöntoimijoiden ja päättäjien ulottuville, jotta muutosta saadaan aikaan. Tämä väitöskirja on siis tutkimus oppikirjojen maailmankuvasta, mutta se on vasta alku, sillä tämä tieto täytyy saada myös käytäntöön aktiivisen keskustelun kautta. 


\section{Lähteet}

Rastas, A. (2005) Rasismi. Oppeja, asenteita, toimintaa ja seurauksia. Teoksessa Rastas, A., Huttunen, L. \& Löytty, O. (toim.) Suomalainen vieraskirja. Kuinka käsitellä monikulttuurisuutta, 69-116. Vastapaino, Tampere.

Souto, A. (2010) "Meidän koulussa ei ole rasismia". Hmm... en usko. Teoksessa Sotkasiira, T., Harinen, P. \& Ronkainen, J. (toim.) Meille saa tulla, 11-12. Suomen Akatemian tutkimushanke Muuttuva kansalaisyhteiskunta - monikulttuurisuus, nuoret ja kulttuurinen kansalaisuus Suomessa. Itä-Suomen yliopisto, Joensuu.

Souto, A., Honkasalo, V. \& Suurpää, L. (2015) Kuuntelemista, sanoittamista ja näkyväksi tekemistä - Tutkija kiistellyn rasismin äärellä. Teoksessa Häkkinen, A. \& Salasuo, M. (toim.) Salattu, hävetty, vaiettu. Miten tutkia piilossa olevia ilmiöitä, 136-162. Osuuskunta Vastapaino, Tampere.

van Dijk, T. A. (1987) Communicating racism. Ethnic prejudice in thought and talk. SAGE Publications, Newbury Park.

\section{Väitöskirjan tiedot}

Eeva Rinne: (Moni)kulttuurinen maailmankuva ja kuulumisen politiikka suomalaisissa peruskoulun oppikirjoissa ja nuorten kokemuksissa. Tampereen yliopiston väitöskirjat 100/2019. ISBN:978-952-03-1182-7 ISSN 2490-0028. Tampereen yliopisto, Tampere 2019. Saatavilla osoitteessa: http://urn.fi/URN:ISBN:978-952-03-1182-7 